\title{
ESTUDIO DE LOS FACTORES DE RIESGO ASOCIADOS A LA PRESENCIA DE LA NOSEMOSIS Y SU IM- PACTO EN LA PRODUCCIÓN DE MIEL EN AMBIENTES SUB-TROPICALES Y TEMPLADOS
}

\author{
Adriana Cecilia Pacini \\ pacini_9@hotmail.com \\ Doctorado en Ciencias Biológicas \\ Director: Dr. Marcelo Lisandro Signorini \\ Co-Directora: Dra. Natalia Verónica Bulacio Cagnolo \\ Lugar de realización: INTA Rafaela. \\ Fecha de la defensa: 18 de marzo de 2019
}

\section{RESUMEN}

Argentina es el segundo exportador mundial de miel ( $13 \%$ del total) y el cuarto productor (contribuyendo con el 6\%). El país comercializa en el exterior el 95\% de la miel producida principalmente a la Unión Europea, Estados Unidos y Japón. No obstante, el aumento de la actividad productiva se ve amenazado tanto por problemas sanitarios como por el avance de la frontera agrícola que reduce la biodiversidad vegetal.

Dentro de los problemas sanitarios destaca la Nosemosis, una enfermedad causada por dos especies de microsporidios (Phylum Microspora), Nosema apis y N. ceranae. Estos agentes son comúnmente encontrados en abejas (Apis mellifera) alrededor del mundo. Son parásitos obligados que se desarrollan en el intestino de las abejas adultas y generan una considerable reducción en la vida de sus hospedadores. La transmisión de Nosema en abejas se realiza mediante la vía fecal-oral por medio del cual los patógenos se diseminan con las heces de individuos infectados a abejas sanas vía ingestión. A nivel mundial se ha generado una gran controversia sobre el rol que tendría estos agentes en la pérdida de colmenas. El presente trabajo tuvo como objetivos identificar, mediante un abordaje epidemiológico, los factores que determinan la ocurrencia de Nosemosis, evaluar el patrón de comportamiento estacional de la enfermedad y caracterizar genéticamente las poblaciones de Nosema spp. en diferentes ecosistemas de nuestro país, buscando estimar el impacto real sobre la producción de miel.

En primera instancia se evaluó la carga de esporos de Nosema spp. mensualmente a lo largo de un año en un total de 19 apiarios ubicados en cinco regiones agro-ecológicas (Santa Fe Sur, Santa Fe Centro, Chaco Húmedo, Chaco de Transición y Chaco Semi-árido) de las provincias de Santa Fe, Chaco y Formosa para determinar el comportamiento estacional de dicho parásito. Los resultados obtenidos de las curvas de esporulación en las provincias analizadas indican un patrón característico, similar al reportado para la especie $N$. apis en otras regiones del mundo. Dicho patrón solo varía en función de las intensidades 
en cada región analizada, siendo las regiones de Santa Fe Sur y Centro y Chaco Semi-árido las que presentaron mayores niveles esporulares.

En las mismas regiones se analizaron muestras para determinar la especie de Nosema spp. presente en 59 apiarios analizados en el período post-cosecha. Se registró infección exclusiva por $N$. ceranae en 37,8\% de los apiarios analizados, mientras que en $26,7 \%$ de los apiarios solo estaban infectados por $N$. apis. El resto, 35,6\% de los apiarios, se encontraron co-infectados por ambas especies de Nosema spp.. Se determinó la relación existente entre la presencia de las distintas especies de Nosema spp. y el haplotipo de abeja que parasitan sin hallar una asociación entre el haplotipo del hospedador y la especie de parásito.

Por último, para identificar factores de riesgo asociados a la ocurrencia de altas cargas de Nosema spp., se realizaron tres muestreos durante un año en 64 apiarios en las regiones mencionadas previamente, junto con encuestas estructuradas realizadas a los apicultores para asociar variables de manejo con el riesgo de alcanzar altas cargas de parasitación. Entre los factores identificados se destacan las diferentes regiones agro-ecológicas y la presencia de Varroa destructor en altos y bajos niveles de infestación. En cuanto al efecto debido a las regiones agro-ecológicas, se observó un marcado gradiente ascendente de Norte a Sur. Asimismo, se determinó una asociación positiva entre los recuentos de esporos de Nosema spp. y los niveles de infestación con Varroa. Aquellas colmenas que presentaban más de 3\% de Varroa en el período post-cosecha tenían mayores niveles esporulares de Nosema spp. En el segundo y tercer muestreo, período de otoño y primavera, se observaron los niveles más altos de esporos de Nosema spp. en las regiones de Sur y Centro de Santa Fe y en Chaco Semi-árido. Con relación a las cargas de Nosema spp. y la infestación con Varroa, la relación se invirtió y se determinó que aquellas colmenas que presentaban menos de $1 \%$ de Varroa en otoño y primavera fueron las que presentaban mayores niveles esporulares. Por otro lado, se determinaron factores de manejo asociados a niveles altos de esporos de Nosema spp. en regiones de Chaco Semi-árido, siendo que aquellas colmenas donde se realizaba el recambio de reinas con una frecuencia mayor a dos años o no se realizaba, presentaban un mayor desarrollo de la parasitosis. Por otro lado, las colmenas que recibieron algún tipo de suplemento polivitamínico o de polen tuvieron mayores niveles esporulares.

Cabe aclarar que la parasitosis no presentó un efecto directo en la producción de miel ni en el estado general de las colmenas durante el año en el que se realizó el trabajo, lo que estaría indicando que, a pesar de encontrarse niveles elevados en algunas regiones, el parásito no llega a generar graves daños en la colmena. 


\section{ABSTRACT}

\section{Study of risk factors associated with the presence of Nosemosis and its impact on honey pro- duction in sub-tropical and temperate environments}

Argentina is the second world exporter of honey ( $13 \%$ of total) and the third producer (contributing with $6 \%)$. The increase in productive activity is threatened by health problems and the advance of the agricultural frontier that reduces plant biodiversity.

Nosemosis, is a disease caused by two species of microsporidiums (Phylum Microspora), Nosema apis and $N$. ceranae. These agents are commonly found in bees (Apis mellifera) around the world. The objective of this thesis was to determine factors that favor the occurrence of Nosemosis, evaluate the pattern of seasonal behavior of the disease and characterize genetically the populations of Nosema spp. in different ecosystems of Argentina, seeking to determine the real impact on honey production. The number of spores and prevalence of Nosema spp. monthly were estimated over a year in a total of 19 apiaries located in five regions (Santa Fe Sur, Santa Fe Centro, Chaco Húmedo, Chaco de Transición and Chaco Semi-arid) to determine the seasonal behavior of the parasite. The results obtained indicate a characteristic pattern, similar to that reported for the Nosema apis in other regions of the world. This pattern only varies depending on the intensities in each region analyzed. Samples of bees were collected and analyzed to determine the species of Nosema spp. present in 59 apiaries during the post-harvest period. The molecular results indicated that both species are present in the regions under study. For identify risk factors associated with the occurrence of high loads of Nosema spp., three samplings were carried out during one year in 65 apiaries in the previously mentioned regions. The different regions analyzed and the presence of Varroa destructor in high and low levels of infestation, were the most relevant factors. 